\title{
ANALISIS PEMAHAMAN MAHASISWA PENDIDIKAN FISIKA \\ UNIVERSITAS JEMBER MELALUI MULTIREPRESENTASI VERBAL DAN GRAFIK TENTANG MANFAAT DAN BAHAYA SINAR UV BAGI KESEHATAN
}

\author{
EIma Tri Istighfarini ${ }^{1}$, Sudarti $^{2}$, Yushardi $^{3}$ \\ ${ }^{1,2,3}$ Program Studi Pendidikan Fisika,FKIP Universitas Jember \\ e-mail: lmatriistighfarini@gmail.com
}

\begin{abstract}
ABSTRAK
Penelitian ini bertujuan untuk menganalisis pemahaman mahasiswa Pendidikan Fisika Universitas Jember mengenai manfaat dan bahaya sinar UV bagi kesehatan melalui multirepresentasi verbal dan grafik. Penelitian ini menggunakan metode deskriptif dengan pendekatan kuantitatif melalui kuisioner terhadap 50 mahasiswa Pendidikan Fisika Universitas Jember yaitu pada mahasiswa semester 2 dan mahasiswa semester 4. Sumber data diperoleh dari kuisioner berbentuk pilihan ganda yang meliputi soal verbal dan grafik sebanyak 10 soal dengan 5 soal verbal dan 5 soal grafik yang telah divalidasi. Hasil jawaban responden akan dianalisis dalam mendeskripsikan kemampuan mahasiswa Pendidikan Fisika Universitas Jember dalam memahami manfaat dan bahaya sinar UV bagi kesehatan melalui multirepresentasi verbal dan grafik. Berdasarkan hasil penelitian yang telah dilakukan menunjukkan bahwa mahasiswa Pendidikan Fisika Universitas Jember lebih memahami materi yang diberikan atau dilihat dalam bentuk soal dengan representasi verbal daripada representasi grafik yaitu dilihat dari nilai rata - rata jawaban benar soal representasi verbal sebesar 71,06\% dan rata - rata jawaban benar untuk soal representasi grafik sebesar 39,76\%. Prosentase sebesar 71,06 \% menunjukkan bahwa tidak semua mahasiswa Pendidikan Fisika Universitas Jember memahami manfaat dan bahaya Sinar UV bagi kesehatan. Hal ini dikarenakan pada mahasiswa semester 2 belum diberikan mata kuliah yang membahas mengenai radiasi matahari dan kecilnya prosentasi jawaban benar dengan representasi grafik karena tingkat kesulitan soal lebih tinggi daripada soal dengan representasi verbal.
\end{abstract}

Kata Kunci: Radiasi UV, Manfaat Sinar UV, Bahaya sinar UV, Representasi Verbal, Representasi Grafik

\section{ABSTRACT}

This study aims to analyze the understanding of Physics Education students at the University of Jember regarding the benefits and dangers of UV rays for health through multi-representation graphs and graphs. This study used a descriptive method with a quantitative approach through questionnaires to 50 students of Physics Education at the University of Jember, namely the 2nd semester students and 4th semester students. The data sources were obtained from a multiple choice questionnaire which included 10 verbal and graphic questions with 5 verbal questions and 5 questions. validated graph questions. The results of respondents' answers will be analyzed in describing the ability of Physics Education students at the University of Jember in understanding the benefits and dangers of UV rays for health through verbal and graphic multi-representation. Based on research that has shown that Physics Education students at the University of Jember better understand the material given or seen in questions with graphical representation results, it is seen from the average value of correct answers to verbal representation questions of $71.06 \%$ and the average correct answers for about graph representation of $39.76 \%$. The percentage of $71.06 \%$ indicates that not all Physics Education students at the University of Jember understand the benefits and dangers of UV rays for health. This is because the sun in semester 2 students has not been given courses that discuss radiation and the small percentage of correct answers with graphical representations because the level of difficulty of the questions is higher related to questions of verbal representation.

Keywords: UV radiation, Benefit of UV rays, Danger of UV Rays, Verbal Representation, Graphic Representation 


\section{PENDAHULUAN}

Keberadaan matahari sangat berpengaruh dalam kehidupan. Sinar matahari atau dikenal dengan sinar UV yang termasuk ke dalam jenis spektrum gelombang elektromagnetik. Paparan sinar UV yang mengenai permukaan kulit dapat menyebabkan permsalahan kulit meskipun dengan adanya paparan sinar matahari ke kulit juga bermanfaat untuk membentuk vitamin $\mathrm{D}$, akan tetapi beberapa dampak negatifnya yang dapat menyebabkan kanker kulit, penurunan elastisitas, atau pun penuaan dini menjadi permasalahan kesehatan yang umum ditemui dalam kehidupan masyarakat. Banyaknya oramg yamg masih menderita kanker kulit menjadi salah satu tanda bahwa kurangnya pengetahuan massyarakat terhadap manfaat dan bahaya sinar UV bagi kesehatan serta cara pencegahan dampak negatif bagi kesehatan khususnya pada kesehatan kulit.

Sinar ultraviolet atau UV dibagi menjadi 3 jenis yaitu UV A, UV B, dan UV C. Pembagian ini berdasarkan besarnya panjang gelombang ketiganya. UV A memiliki panjang gelombang $(315-400) \mathrm{nm}$, UV B memiliki panjang gelombang $(280-315) \mathrm{nm}$, dan UV C memiliki panjang gelombang sebesar $(100-280) \mathrm{nm}$. Sinar UV C ini jarang yang sampai ke bumi karena diserap oleh ozone atau partikel oksigen , sedangkan sinar UV A dan UV B ( sekitar $10 \%$ $30 \%$ ) sampai ke permukaan bumi. Tidak semua sinar UV B sampai ke permukaan bumi karena ada yang diabsorbsi oleh stratosfer( Park et al, 2019).

Pada gelombang pasti memiliki panjang gelombang, frekuensi, dan cepat rambat. Diantara ketiganya memiliki hubungan yang dijelaskan dengan persamaan $v=\lambda \mathrm{f}$ dengan $\mathrm{v}$ merupakan cepat rambat gelombang $(\mathrm{m} / \mathrm{s}), \lambda$ merupakan panjang gelombang $(\mathrm{m})$, dan $\mathrm{f}$ merupakan frekuensi (Hz) (Sutopo, 2016 : 43). Berdasarkan persamaan tersebut dapat diketahui hubungan diantara ketiganya yaitu panjang gelombang $(\lambda)$ berbanding terbalik dengan frekuensi dan berbanding lurus dengan cepat rambat (v) , sehingga semakin besar panjang gelombangnya maka frekuensi akan semakin kecil. Max Planck mengemukakan persamaan $\mathrm{E}=$ nhf dengan $\mathrm{E}$ merupakan energi, dan $\mathrm{h} v$ merupakan kuantum energi dengan hubungan yang terjadi antara $\mathrm{v}$ dan $\mathrm{f}$ yaitu $\mathrm{v}=\lambda \mathrm{f}$. Teori Max Planck ini diperoleh dari asumsi terhadap benda hitam sebagai kumpulan osilator - osilator dalam kesetimbangan medan radiasi.

Paparan sinar UV A dapat megredasi katalis heme menjadi besi, biliverdin, karbon monoksida yang dapat mengakibatan imunoprotektif yang juga bisa menghasilkan oksida nitart, meningkatkan kardiovaskuler, serta menjadi neurotransmitter dan pada UVA serta UV B ini berperan dalam pembentukkan vitamin D yang diperlukan oleh tubuh (Grigalavicius et al, 2015). Vitamin D diproduksi karena terpaparnya kulit oleh sinar UVB yang pro vitamin D3, dan pada membrane plasma ini membentuk pra vitamin D3. Pre vitamin D3 ini dapat diubah menjadi vitamin D yang disalurkan ke seluruh tubuh. Iradiasi sinar UV C juga dapat dijadikan sebagai disinfektan. Pada iradiasi UV $\mathrm{C}$ ini dapat membunuh mikroorganisme pembentuk spora, mikrobakteri, atau bakteri resisten. Sinar UVA dapat menjangkau secara efektif melalui lapisan atas kulit ke dalam dermis manusia dan sistem kapiler dermal. Iradiasi UV mengaktifkan faktor pertumbuhan permukaan sel dan reseptor sitokin pada keratinosit dan fibroblas di kulit manusia yang penting untuk regulasi proliferasi dan kelangsungan hidup sel (Donglikar dan Deore, 2016 : 171).

Menurut (Maeda, 2018 : 1) paparan dalam jangka panjang UV A dan UV B ini dapat mengubah sifat dari serat kolagen dermis yang menurunkan elastisitas kulit yang dapat menyebabkan keriput, penurunan elastisitas kulit secara permanen, dan juga dapat menyebabkan evaluasi agen anti fotoaging. Menurut (Grigalavicius et al, $2016: 23$ ) paparan radiasi sinar UV dapat menjadi faktor lingkungan yang bisa menyebabkan kanker kulit.

Menurut (Donglikar dan Deore, 2016). UV B merupakan salah satu penyebab utama dalam menginduksi karsinoma sel basal (BCC) dan karsinoma sel skuamosa (SCC). Sinar UVA dapat menjangkau secara efektif melalui lapisan atas kulit ke dalam dermis manusia dan sistem kapiler dermal. Oksidasi protein dan lipid terjadi di epidermis dan dermis kulit manusia yang terjadi bersamaan dengan penipisan antioksidan enzimatik dan non-enzimatik yang signifikan

Sebagai mahasiswa fisika tentunya harus memahami mengenai manfaat dan bahaya sinar UV 
bagi kesehatan karena hal ini juga erat kaitannya dengan pembelajaran fisika yang ada di SMA atau pun pembelajaran yang ada di perkuliahan khususnya pada program studi pendidikan fisika. Terlebih lagi dampak negatif sinar UV bagi kesehatan tubuh harus diperhatikan sehingga terdapat pencegahan - pencegahan yang dilakukan untuk mengurangi atau mencegah dampak negatif sinar UV bagi kesehatan tubuh. Salah satu pencegahan terhadap dampak negatif yang dapat dilakukan adalah dengan menggunakan lotion ber spf yang berguna melindungi kulit dari sinar UV, tidak terlalu lama beraktivitas di luar ruangan yang dapat menyebabkan semakin lama untuk terpapar sinar UV, dan juga dengan menekankan lagi mengenai bahaya yang dpaat ditimbulkan oleh sinar UV pada mahasiswa Pendidikan Fisika Universitas Jember sehingga dapat mengingatkan atau menyadarkan agar mahasiswa Pendidikan Fisika Universitas Jember mencegah bahaya sinar UV bagi kesehatan terutama sebagai penyebab kanker kulit yang menggunakan beberapa representasi untuk dapat digunakan dalam mengetahui pemahaman mahasiswa Pendidikan Fisika . Kegiatan belajar mengajar dilakukan dengan melalui beberapa representasi agar siswa atau mahasiswa dapat mengetaahui tentang materi yang sedang diajarkan. Ada beberapa jenis representasi yang dapat digunakan pada kegiatan belajar mengajar yang berupa representasi verbal, representasi gambar, representasi grafik, representasi tabel, representai matematis, atau pun gabungan dari beberapa representasi yang dikenal dengan multirepresentasi.

Kemampuan dalam memecahkan suatu permasalahan melalui representasi sangat berperan penting dalam proses pembelajaran fisika. Eksternal representasi yang diterapkan pada pembelajaran bisa mengurangi beban kognitif siswa dalam memecahkan masalah, dan membiasakan siswa untuk menulis jawaban secara terperinci(Putra et al, 2020). Kemampuan dalam menerjemahan representasi grafik, tabel, simbolik dan verbal sangat penting dalam memahami dan mengkomunikasikan suatu konsep matematis. Namun masih banyak siswa yang kesulitan dalam menentukan representasi simbolik yang sesuai dengan hubungan yang direpresentasikan dalam bentuk grafik atau tabel.

Berdasarkan suatu penelitian, ditemukan bahwa siswa belum mampu menerjemahkan jenis representasi, terutama konteks fisik ke grafik. Mahasiswa lebih berhasil dalam menentukan grafik yang benar daripada membuat sebuah grafik (Rahmawati et al, 2017).

Informasi yang diberikan dalam betuk kata kata diterima dalam bentuk verbal, sedangkan pada informasi yang diterima dalam bentuk gambar akan dalam bentuk visual. Terdapat 3 proses yang berlangsung ketika seseorang menerima informasi baik yang berupa verbal atau visual dalam waktu yang bersamaan, yaitu dapat membuat gambaran verbal serta kesesuaian dengan informasi verbal yang diterima, membuat gambaran visual serta kesesuaian dengan informasi visual yang diterima, serta dapat membuat kesesuaian hubungan antara gambaran verbal dengan gambaran visual yang telah diterima. (Susana , 2019 : 26) Media visual dapat membantu dalam pemahaman dan penguatan ingatan. Bentuk visual dapat berupa gambar representasi, seperti gambar, lukisan, foto , serta diagram yang menggambarkan hubungan antara konsep , organisasi, dan struktur isi materi, dan juga grafik seperti tabel, grafik, dan chart (bagan) yang menyajikan gambar / kecenderungan data atau hubungan seperangkat gambar atau angka angka (Kustandi dan Darmawan , 2020 : 37)

Berdasarkan uraian di atas, sinar UV memiliki beberapa jenis dengan manfaat dan bahaya bagi kesehatan yang berbeda - beda. Sebagai mahasiswa Pendidikan Fisika Universitas Jember seharusnya sudah memahami mengenai manfaat dan bahaya sinar UV bagi kesehatan sehingga untuk mengetahui pemahaman mahasiswa Pendidikan Fisika Universitas Jember terkait manfaat dan bahaya sinar UV bagi kesehatan maka dilakukan penelitian melalui kuisioner yang menggunakan multirepresentasi verbal dan grafik.

\section{METODE PENELITIAN}


Metode yang digunakan dalam penelitian ini menggunakan pendekatan kuantitatif dengan jenis penelitian yang berupa deskriptif. Pada penelitian ini digunakan untuk memperoleh data pemahaman mahasiswa semester 2 dan semester 4 Pendidikan Fisika Universitas Jember mengenai manfaat dan bahaya sinar UV bagi kesehatan melalui multirepresentasi verbal dan grafik melalui kuisioner dengan bobot soal grafik lebih sulit karena data disajikan pada informasi yang diberikan untuk menjawab soal representasi verbal dan harus dianalisis lebih dalam lagi untuk menentukan jawaban yang benar atau sesuai. Penyebaran kuisioner dilaksanakan pada tanggal 17 April 2021 dimana kuisioner yang dibuat terdiri atas 5 soal representasi verbal dan 5 soal representasi grafik yang telah divalidasi. Kuisioner dibuat melalui google form dengan responden sebanyak 50 mahasiswa semester 2 dan semester 4 Pendidikan Fisika Universitas Jember dan kuisioner disebarkan menggunakan media sosial whatsapp sehingga responden bisa mengisi kuisioner di rumah masing - masing dan juga dengan waktu yang disesuaikan dengan responden dengan batas waktu pengisian selama 3 hari.

\section{HASIL DAN PEMBAHASAN}

Berdasarkan data primer yang diperoleh dari penyebaran kuisioner kepada 50 mahasiswa Pendidikan Fisika Universitas Jember didapatkan hasil prosentasi jawaban benar kuisioner yang disajikan dengan 5 soal dengan representasi verbal dan 5 soal dengan representasi grafik dan perbandingan jawaban benar untuk soal dalam bentuk representasi verbal dan soal dalam bentuk representasi grafik. Pada soal dengan representasi verbal diberikan informasi dalam bentuk teks sehingga mahasiswa dapat memilih jawaban benar dengan membaca informasi yang telah disajikan.

Sedangkan pada soal representasi grafik disajikan grafik baik dalam bentuk diagram batang atau pun grafik garis dengan pertanyaan yang ditanyakan seputar konsep dan juga berkaitan dengan besaran yang disajikan ke dalam grafik sehingga untuk memilih jawaban benar mahasiswa harus dapat membaca grafik dan menghubungkan besaran yang diperoleh dengan persamaan yang didapatkan dari informasi yang diberikan pada soal representasi verbal. Data prosentasi untuk jawaban benar pada soal representasi verbal dan representasi grafik dapat dilihat pada tabel 1.

Tabel 1. Prosentasi Jawaban Benar untuk Soal

Representasi Verbal dan Representasi Grafik

\begin{tabular}{|c|l|c|}
\hline $\begin{array}{c}\text { Nomor } \\
\text { Soal }\end{array}$ & \multicolumn{1}{|c|}{$\begin{array}{c}\text { Jenis } \\
\text { Representasi }\end{array}$} & Presentasi \\
\hline 1 & Verbal & $64 \%$ \\
\hline 2 & Verbal & $66 \%$ \\
\hline 3 & Verbal & $72 \%$ \\
\hline 4 & Verbal & $70 \%$ \\
\hline 5 & Verbal & $83,3 \%$ \\
\hline 6 & Grafik & $34 \%$ \\
\hline 7 & Grafik & $40,8 \%$ \\
\hline 8 & Grafik & $40 \%$ \\
\hline 9 & Grafik & $30 \%$ \\
\hline 10 & Grafik & $54 \%$ \\
\hline
\end{tabular}

Sumber : Data diolah

Sedangkan perbandingan prosentasi jawaban benar untuk soal representasi verbal dan representasi grafik secara keseluruhan adalah $65,66 \%: 34,34 \%$ dan dapat dilihat melalui diagram lingkaran yang disajikan.
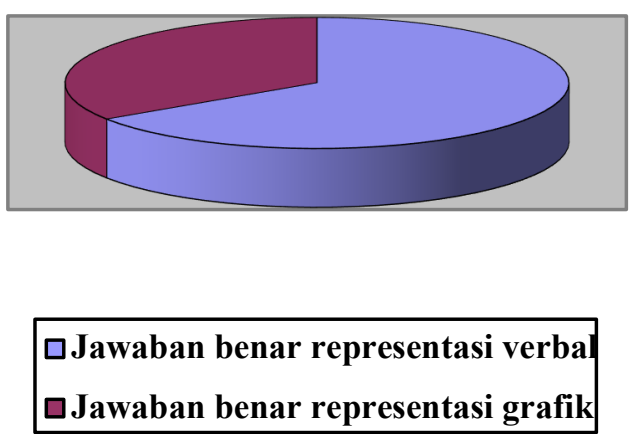

Gambar 1. Diagram Lingaran Prosentasi Rata Rata Jawaban Benar dengan Representasi Verbal dengan Representasi Grafik 
Berdasarkan data primer yang diperoleh dari kuisioner didapatkan bahwa prosentase rata rata jawaban benar mahasiswa Pendidikan Fisika Universitas Jember dengan soal yang menggunakan representasi verbal sebesar 71,06\% dengan nilai prosentase tiap soal yaitu $64 \%, 66 \%$, $72 \%, 70 \%$, dan $83,3 \%$ sedangkan prosentase ratarata jawaban benar untuk soal dengan representasi grafik yaitu sebesar $39,76 \%$ dengan nilai prosentase tiap soalnya yaitu sebesar $34 \%, 40,8 \%$, $40 \%, 30 \%$, dan $54 \%$.

Data pemahaman mahasiswa Pendidikan Fisika Universitas Jember mengenai manfaat dan bahaya sinar UV bagi kesehatan menunjukkan bahwa prosentase jawaban benar untuk soal verbal lebih besar daripada soal dengan representasi grafik. Hal ini menunjukkan bahwa mahasiswa Pendidikan Fisika Universitas Jember lebih memahami materi yang diberikan atau soal yang disajikan dengan representasi verbal dibandingkan jika menggunakan representasi grafik. Hal tersebut juga didukung dengan hasil penelitian pada suatu jurnal (Rahmawati et al, 2017). yang menyatakan bahwa kemampuan dalam menerjemahan representasi grafik, tabel, simbolik dan verbal sangat penting dalam memahami dan mengkomunikasikan suatu konsep matematis. Namun masih banyak siswa yang kesulitan dalam menentukan representasi simbolik yang sesuai dengan hubungan yang direpresentasikan dalam bentuk grafik atau tabel Pada tingkat kesulitan soal pun lebih tinggi soal - soal dengan representasi grafik dibandingkan dengan soal dengan representasi verbal karena pada soal representasi verbal terdapat informasi yang diberikan yang berkaitan dengan hal yang ditanyakan sedangkan pada soal representasi grafik tedapat soal yang tidak hanya membaca grafik saja untuk memperoleh data yang dibutuhkan tetapi juga harus memahami konsep terkait radiasi matahari yang dapat diketahui hubungan antara besarannya melaluai informasi yang disajikan pada soal representasi verbal.

Selain itu tingkat prosentasi yang ditunjukkan pada jawaban benar representasi verbal dengan nilai $71,06 \%$ menunjukkan bahwa mahasiswa semester 2 dan 4 Pendidikan Fisika Universitas Jember atau responden memiliki tingkat pemahaman soal melalui representasi verbal yang tergolong cukup baik karena nilai representasi kurang dari $80 \%$ dan bahkan untuk pemahaman mahasiswa semester 2 dan 4 Pendidikan Fisika Universitas Jember yang menggunakan representasi grafik memiliki nilai sebesar 39,76\% dan nilai prosentasi ini menunjukkan bahwa tingkat pemahaman melalui representasi grafik serta kemampuan menganalisis melalui grafik dan verbal masih kurang. Sinar UV yang memiliki bahaya dan manfaat sekaligus harus lebih diperhatikan lagi bukan hanya untuk mahasiswa semester 2 dan 4 Pendidikan Fisika Universitas Jember tetapi juga oleh seluruh masyarakat sebab jika kita dapat mengetahui kelebihan dan kekurangan dari suatu hal kita dapat menggunakan hal tersebut lebih bijak lagi dengan kata lain kita dapat mengurangi atau mencegah dampak negatif sinar UV dan memanfaatkan sebaik - baiknya untuk manfaat atau dampak positif yang dimiliki oleh sinar UV.

\section{KESIMPULAN}

Berdasarkan hasil penelitian dan pembahasan data yang telah dilakukan menunjukkan beberapa kesimpulan yiatu :

1. Mahasiswa Pendidikan Fisika Universitas Jember memiliki kemampuan representasi verbal yang cukup baik yaitu ditandai dengan nilai rata -

rata jawaban benar dengan prosentasi sebesar $71,06 \%$.

2. Mahasiswa Pendidikan Fisika Universitas Jember memiliki kemampuan representasi grafik yang kurang baik yaitu ditandai dengan nilai rata - rata jawaban benar dengan prosentasi sebesar 39,76\% atau nilai ini terbilang sangat rendah.

3. Dan bahaya sinar UV terkait energi radiasi dikarenakan sebagian besar responden kuisioner adalah mahasiswa semester 2 yang belum menempuh mata kuliah yang berkaitan dengan radiasi matahari sehingga konsep mengenai energi, frekuensi, dan panjang gelombang diperoleh dengan mengingat materi 
dari pelajaran fisika ketika SMA dan pada soal representasi grafik pun bukan hanya membaca grafik saja tetapi juga menghubungkannya dengan konsep radiasi matahari sehingga tingkat kesulitannya lebih tinggi daripada soal dengan representasi verbal.

\section{DAFTAR PUSTAKA}

Grigalavicius, M., J. Moan, A. Dahlback, dan A. Juzeniene. (2016). Daily, seasonal, and latitudinal variations in solar ultraviolet A and $\mathrm{B}$ radiation in relation to vitamin $\mathrm{D}$ production and risk for skin cancer. International Journal of Dermatology : 23.

Harinko , R. dan S.J. Hayati. (2019). NonMelanoma Skin Cancer (NMSC) pada Pekerja Luar Ruangan dan Intervensinya. Jounal Agromedicine.6(2) : 405 - 406.

Park, D.H., S.T. Oh, dan J.H. Lim. (2019). Development of a UV Index Sensor-Based Portable Measurement Device with the EUVB Ratio of Natural Light. Journal Sensors : 1-2.

Putra A.I.A., N.S. Aminah, dan A. Marzuki. (2020). Analysis of Students' Multiple representation-based Problem - solving Skills. Journal of Education Science and Technology. 6(1) : 100.

Rahmawati D., Purwanto, Subanji, E. Hidayanto, dan R. B. Anwar. (2017). Process of Mathematical Representation Translation from Verbal into Graphic. International Electronic Journal Of Mathematics Education. 12 (3) : 369.

Sutopo.( 2016). PEMAHAMAN MAHASISWA TENTANG KONSEP-KONSEP DASAR GELOMBANG MEKANIK. Journal Pendidikan Fisika Indonesia. 12(1) : 43.

Susana , A. (2019). Pembelajaran Discovery Learning menggunakan Multimedia Interaktif . Bandung : Polar.

Kustandi , C. dan D. Darmawan. (2020).

Pengembangan media pembelajaran

Konsep \& Aplikasi Pengemabangan Media Pembelajaran bagi Pendidikan di Sekolah dan masyarakat. Jakarta : Kencana. 